Central Marine Fisheries Research Institute, Cochin, and Biological Oceanography Division, National Institute of Oceanography, Cochin

\title{
Some Problems Related to the Measurements of Primary Production Using Radiocarbon Technique
}

\section{Contents}

1. Introduction . . . . . . . . . . . . . . . . . . . . . . . . . . 535

2. Effect of bottle size on the measurement of primary production . . . . . . . . 536

a) Experimental procedure . . . . . . . . . . . . . . . . . . 536

b) Results . . . . . . . . . . . . . . . . . . . . . . . . . . . . . 537

c) Conclusions . . . . . . . . . . . . . . . . . . . . . . . . . . . . . . 539

3. Effect of different amounts of material on self-absorption . . . . . . . . . . . 539

a) Experimental procedure . . . . . . . . . . . . . . . . . . . . . 541

b) Results . . . . . . . . . . . . . . . . . . . . . . . . . . . . . . . 541

c) Conclusions . . . . . . . . . . . . . . . . . . . . . . . . . . . . . . 544

4. Effect of organic pollutants on light and dark bottles . . . . . . . . . . . . . 544

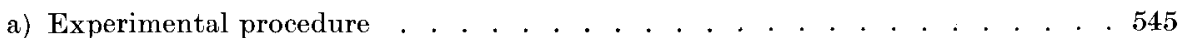

b) Results . . . . . . . . . . . . . . . . . . . . . . . . . . 545

c) Conclusions . . . . . . . . . . . . . . . . . . . . . . . . . . 548

5. Summary . . . . . . . . . . . . . . . . . . . . . . . . . . . . . . . 548

6. Literature cited . . . . . . . . . . . . . . . . . . . . . . . . . 549

\section{Introduction}

The SCOR/IBP Working Group-24 held its first meeting in Southampton (U.K.) from 30 July to 1 August 1968 under the chairmanship of Dr. T. R. Parsons (Canada). The members of this Working Group were: Dr. O. I. KobLentz-Mishke (U.S.S.R.), Prof. S. Ichimura (Japan), Dr. P. D. V. Savage (U.K.) and Dr. S. Z.QASIM (India). The terms of reference of the Working Group were: "To review and suggest the best methods for estimating primary production under special conditions, such as those found beneath polar ice, and the turbid conditions found in estuaries, heavily polluted waters and exceptionally eutrophic or oligotrophic waters".

The Working Group in its first report SCOR (1969) indicated that the problems suggested by the terms of reference were so diverse that it may not be possible to include in the discussions the various general problems connected with methodology and the specific problems related to the measurements of primary production in different environments. Moreover, the participants were not in complete agreement on several aspects and suggested that experiments should be carried out by Dr. S. Z. QASIM and Dr. P. D. V. SAVAGE under tropical 
and temperate conditions respectively and the results of these experiments should be discussed in the next meeting of the Working Group. The following three main problems were suggested (see SCOR 1969):

1. Effect of bottle size on the measurement of primary production

2. Effect of different amounts of material on self-absorption

3. Effect of organic pollutants on light and dark bottles.

Consequently, several series of experiments were carried out on the three problems by the present authors at Cochin (India) and by Dr..SAVAGE and his colleagues in Southampton (U.K.). The results of all these experiments were discussed during the second meeting of the Working Group from 9 to 12 November 1970 in Nanaimo, B.C., Canada. A summary of the results both from Cochin and Southampton has been included in the final report of the Working Group which is to be published by SCOR under the title "A guide to the measurements of primary production under some special conditions".

However, since the three problems investigated are of much interest to all those who are involved in measuring primary production using the radiocarbon technique of STEEmanN Nielsen (1952), it was felt in the meeting itself that full details of all the experiments should be published as a separate communication. The present paper gives the results of the experiments carried out at Cochin, and a similar communication from Southampton is awaited for comparison between the results under temperate and tropical conditions.

\section{Effect of bottle size on the measurement of primary production}

In none of the earlier reports, handbooks or manuals (see. e.g. UNEsco 1967, Strickland and Parsons 1968, IBP Handbook 1969, National Academy of SCIENCES REPORT 1969), the effect of bottle size on primary production has been mentioned. Thus on several instances, an individual investigator, while starting the experiment, is faced with the problem of selecting the right sized bottles to ensure maximum accuracy in his measurements. SoEder and TALLING (1969) have recommended that the volume of the bottles should not be less than $100 \mathrm{ml}$.

\section{a) Experimental procedure}

For conducting controlled experiments on this effect, bottles (Pyrex) of three different capacities $-60 \mathrm{ml}, 120 \mathrm{ml}$ and $300 \mathrm{ml}$ - were taken. All bottles in each batch were carefully selected. These were of similar size and of identical transparency. Each bottle was thoroughly washed with chromic acid and dried. A set of three replicates of each size was then taken and all the bottles were filled with Millipore-filtered seawater. The volumes of water used were:

$50 \mathrm{ml}$ in $60 \mathrm{ml}$ bottles

$100 \mathrm{ml}$ in $120 \mathrm{ml}$ bottles

$250 \mathrm{ml}$ in $300 \mathrm{ml}$ bottles

Healthy and fast-growing unialgal cultures of phytoplankton organisms were taken. These were not bacteria-free. Each culture was considerably diluted by the culture-medium so as to keep the counts low, thus allowing sufficient accuracy in counting after the in- 
cubation, and to avoid self-absorption that may arise as a result of deposition of the organisms on the filters. The following volumes of cultures were used in each set of experiments:

$$
\begin{aligned}
& 1 \mathrm{ml} \text { in } 50 \mathrm{ml} \\
& 2 \mathrm{ml} \text { in } 100 \mathrm{ml} \\
& 5 \mathrm{ml} \mathrm{in} 250 \mathrm{ml}
\end{aligned}
$$

If, however, the concentrations of the cultures were found to be too high or low, their volumes were adjusted accordingly, maintaining the above ratio in each set of bottles. ${ }^{14} \mathrm{C}$ ampoules of $1 \mathrm{ml}$ and $4 \mu \mathrm{C}$, supplied by the Bhabha Atomic Research Centre, Trombay, Bombay, India, were used. The ampoules were especially tested for any possible contamination with toxic substances and had a $\mathrm{pH}$ of about 9.0. One ampoule was added to each bottle. The addition of ${ }^{14} \mathrm{C}$ in bottles was done in much subdued light and all bottles were immediately suspended in an aquarium tank containing freshwater. The dimensions of the especially designed tank were $68 \mathrm{~cm} \times 62 \mathrm{~cm} \times 30 \mathrm{~cm}$. The tank had a front panel of clear glass and opaque panels on all other three sides.

A panel of cool, fluorescent light, exactly of the size of the aquarium glass was used during the incubation. It had a light intensity of 8,000 lux. Incubation time in experiments was $3-4$ hours. The duration of exposure to light for each bottle was determined exactly from the time the light-panel was switched on until the time each bottle was withdrawn, just before filtration. Millipore filters of $0.45 \mu$ pore size and $37 \mathrm{~mm}$ circles were used. Filtration cup consisted of sintered glass funnel. The vacuum applied during filtration was about $1 / 3$ atmosphere. Filtration was done in subdued light and the filtration time for each set of bottles was $1-2$ minutes for $50 \mathrm{ml}$ bottles, $2-3$ minutes for $100 \mathrm{ml}$ bottles and $<5$ minutes for $250 \mathrm{ml}$ bottles. The filters were dried in special holders in a dessicator and counted using a windowless gas flow proportional counter with an efficiency of $30 \%$. Each filter was counted up to 10,000 counts to get $1 \%$ statistical accuracy. The counts of replicates were averaged.

\section{b) Results}

In the first series of four experiments, only the light bottles were taken as a test case. Tables 1-4 give the counts from the light bottles of different sizes when three different cultures were used. The tables also give the standard

Table 1. Effect of bottle size on the rate of ${ }^{14} \mathrm{C}$ uptake in Ceratium.

Experiment was done on 20-9-1969

\begin{tabular}{c|c|c}
$\begin{array}{c}\text { Volume taken } \\
(\mathrm{ml})\end{array}$ & $\begin{array}{c}\text { Counts/min } \\
\text { Light bottles }\end{array}$ & S. D. \\
50 & 1233 & \pm 23.2 \\
100 & 1287 & \pm 23.7 \\
250 & 1350 & \pm 17.0
\end{tabular}

Table 2. Effect of bottle size on the rate of ${ }^{14} \mathrm{C}$ - uptake in Ceratium.

Experiment was done on 23-9-1969

\begin{tabular}{c|c|c}
$\begin{array}{c}\text { Volume taken } \\
(\mathrm{ml})\end{array}$ & $\begin{array}{c}\text { Counts/min } \\
\text { Light bottles }\end{array}$ & S. D. \\
\hline 50 & 437 & \pm 10.8 \\
100 & 354 & \pm 11.0 \\
250 & 392 & \pm 11.4
\end{tabular}


Table 3. Effect of bottle size on the rate of ${ }^{14} \mathrm{C}$ uptake in Dunaliella $\left.{ }^{1}\right)$.

Experiment was done on 25-9-1969

\begin{tabular}{c:cc}
$\begin{array}{c}\text { Volume taken } \\
(\mathrm{ml})\end{array}$ & $\begin{array}{c}\text { Counts/min } \\
\text { Light bottles }\end{array}$ & S. D. \\
\hdashline 50 & 403 & \pm 12.6 \\
100 & 418 & \pm 13.1 \\
250 & 409 & \pm 12.7
\end{tabular}

1) Dunaliella culture was obtained from The Laboratory, Plymouth, U. K. in 1967. It was sub-cultured in tropical conditions at Cochin and maintained continuously at room temperature.

Table 4. Effect of bottle size on the rate of ${ }^{14} \mathrm{C}$ uptake in Platymonas ${ }^{1}$.

Experiment was done on 16-1-1970

\begin{tabular}{|c|c|c|}
\hline $\begin{array}{l}\text { Volume taken } \\
\qquad(\mathrm{ml})\end{array}$ & $\begin{array}{l}\text { Counts/min } \\
\text { Light bottles }\end{array}$ & S. D. \\
\hline 50 & 1029 & \pm 18.3 \\
\hline 100 & 978 & \pm 25.2 \\
\hline 250 & 1073 & \pm 15.6 \\
\hline
\end{tabular}

1) Platymonas culture was obtained from The Laboratory, Plymouth, U.K. in 1967. It was subcultured in tropical conditions at Cochin and maintained continuously at room temperature.

deviation for the counts in replicates. As can be seen from these tables, the average counts in each set of experiments agreed very closely.

In the next series of three experiments, both light and dark bottles were used. The average counts in both these types of bottles have been given separately in Tables 5-7. The variations in each set of bottles were not too large and a close agreement in the rate of photosynthesis was obtained from the different volumes of samples incubated.

In the third series of experiments the bottles used for incubation contained $100 \mathrm{ml}$ and $250 \mathrm{ml}$ samples, but the volumes filtered from these were in parts. Thus from $100 \mathrm{ml}, 2$ sub-samples $(50 \mathrm{ml}$ each) and from $250 \mathrm{ml}, 5 \mathrm{sub}$-samples ( 2 of $25 \mathrm{ml}, 2$ of $50 \mathrm{ml}$ and 1 of $100 \mathrm{ml}$ ) were withdrawn and filtered separately. Replicate samples of 100 and $250 \mathrm{ml}$ from the dark bottles were not filtered in parts. Table 8 gives the counts of each sub-sample taken from the light bottles, counts from the dark bottles and the rate of photosynthesis calculated from each sub-sample. As can be seen from the table when the volumes of the subsamples were the same, the counts were almost alike, but as the volumes were doubled, the counts were also doubled and so on. The rates of photosynthesis calculated from all the sub-samples were very close to each other (range $=$ $5.04-6.26 \mathrm{mg} \mathrm{C} / \mathrm{m}^{3} / \mathrm{h}$; mean $\left.=5.87 \mathrm{mg} \mathrm{C} / \mathrm{m}^{3} / \mathrm{h} ; \mathrm{S} . \mathrm{D} .=0.44\right)$. 
Table 5. Effect of bottle size on the rate of ${ }^{14} \mathrm{C}$ uptake in Dinophysis.

Experiment was done on 28-1-1970

\begin{tabular}{rcc|cc:c}
$\begin{array}{c}\text { Volume } \\
\text { used } \\
(\mathrm{ml})\end{array}$ & $\begin{array}{c}\text { Counts/min } \\
\text { light bottles }\end{array}$ & S. D. & $\begin{array}{c}\text { Counts/min } \\
\text { Dark }\end{array}$ & S. D. & $\begin{array}{c}\text { Rate of } \\
\text { Photosynthesis } \\
\mathrm{mgC} / \mathrm{m}^{3} / \mathrm{h}\end{array}$ \\
\hline $\mathbf{5 0}$ & 4252 & \pm 36.5 & 132 & \pm 9.3 & 5.37 \\
$\mathbf{1 0 0}$ & 4416 & \pm 43.5 & 71 & \pm 9.8 & 5.66 \\
$\mathbf{2 5 0}$ & 4055 & \pm 49.0 & 116 & \pm 9.5 & 5.13
\end{tabular}

Table 6. Effect of bottle size on the rate of photosynthesis of Biddulphia.

Experiment was done on 30-1-1970

\begin{tabular}{c:ccccc}
$\begin{array}{c}\text { Volume } \\
\text { 1sed } \\
(\mathrm{ml})\end{array}$ & $\begin{array}{c}\text { Counts/min } \\
\text { Light bottles }\end{array}$ & S. D. & $\begin{array}{c}\text { Counts } / \mathrm{min} \\
\text { Dark }\end{array}$ & S. D. & $\begin{array}{c}\text { Rate of } \\
\text { Photosynthesis } \\
\mathrm{mgC} / \mathrm{m}^{3} / \mathrm{h}\end{array}$ \\
\hline 100 & 2342 & \pm 49.4 & 222 & \pm 11.1 & 2.58 \\
250 & 2408 & \pm 29.9 & 273 & \pm 12.2 & 2.60
\end{tabular}

Table 7. Effect of bottle size on the rate of photosynthesis of Ceratium. Experiment was done on 3-2-1970

\begin{tabular}{|c|c|c|c|c|c|}
\hline $\begin{array}{l}\text { Volume } \\
\text { used } \\
(\mathrm{ml})\end{array}$ & $\begin{array}{l}\text { Counts/min } \\
\text { Light bottles }\end{array}$ & S. D. & $\begin{array}{c}\text { Counts } / \text { min } \\
\text { Dark }\end{array}$ & S. D. & $\begin{array}{c}\text { Rate of } \\
\text { Photosynthesis } \\
\mathrm{mgC} / \mathrm{m}^{3} / \mathrm{h}\end{array}$ \\
\hline 50 & 2316 & \pm 24.0 & 226 & \pm 12.0 & 2.86 \\
\hline 100 & 2363 & \pm 24.6 & 228 & \pm 11.0 & 2.92 \\
\hline 250 & 2254 & \pm 22.4 & 147 & $\pm \quad 6.6$ & 2.88 \\
\hline
\end{tabular}

From these experiments it is clear that in short-term experiments there is no marked effect of bottle size on the rate of photosynthesis. There were significant differences neither in the counts nor in the calculated values of production rates from the volumes of the incubated samples. It is, therefore, suggested that in eutrophic environments, smaller bottles should be used and in oligotrophic environments larger bottles are preferable. These would keep the counts low, well within the limits of the counting efficiency of the counter used, and will give a greater accuracy in results.

\section{Effect of different amounts of material on self-absorption}

The presence of suspended material increases the "thickness" of the residue deposited on the filters and reduces the counts by absorbing the soft beta rays from ${ }^{14} \mathrm{C}$. This effect is known as "self-absorption". STRICKLAND and Parsons (1968) give the loss of radiation in $20 \mathrm{mg} / \mathrm{cm}^{2}$ thickness as $90 \%$ in terms of zero thickness. Self -absorption is generally determined from the count rates of $\mathrm{BaCo}_{3}$ deposits of varying thickness prepared from the aliquots of ${ }^{14} \mathrm{C}$ 
Table 8. Effect of bottle size on the rate of photosynthesis of Dinophysis when the total volume was filtered in parts, a - e show the volumes taken as subsamples. Experiment was done on 28-1-1970

\begin{tabular}{|c|c|c|c|c|c|c|c|c|c|c|c|c|c|c|c|c|c|c|}
\hline \multirow{2}{*}{$\begin{array}{c}\text { Volume } \\
\text { used for } \\
\text { incuba- } \\
\text { tion (ml) } \\
\text { Light }\end{array}$} & \multicolumn{5}{|c|}{$\begin{array}{c}\text { Volume filtered }(\mathrm{ml}) \\
\text { in parts } \\
\text { Light }\end{array}$} & \multicolumn{5}{|c|}{ Counts per minute } & \multirow{2}{*}{$\begin{array}{l}\text { Volume } \\
\text { used for in- } \\
\text { cubation } \\
\text { (ml) } \\
\text { Dark }\end{array}$} & \multirow{2}{*}{$\begin{array}{c}\text { Volume } \\
\text { filtered } \\
(\mathrm{ml}) \\
\text { Dark }\end{array}$} & \multirow{2}{*}{$\begin{array}{l}\text { Counts/ } \\
\text { min } \\
\text { Dark }\end{array}$} & \multicolumn{5}{|c|}{$\begin{array}{l}\text { Rate of photosynthesis } \\
\mathrm{mgC} / \mathrm{m}^{3} / \mathrm{h}\end{array}$} \\
\hline & (a) & (b) & (c) & (d) & (e) & (a) & (b) & (c) & (d) & (e) & & & & (a) & (b) & (c) & (d) & (e) \\
\hline 100 & 50 & 50 & - & - & - & 2183 & 2429 & - & - & $\overrightarrow{-}$ & 100 & 10 & 50 & 5.62 & 6.26 & - & - & - \\
\hline 250 & 25 & 25 & 50 & 50 & 100 & 485 & 458 & 917 & 976 & 1579 & 250 & 250 & 94 & 6.21 & 6.21 & 5.68 & 6.24 & 5.04 \\
\hline
\end{tabular}

Table 9. Effect of increasing quantities of inert material on the ${ }^{14} \mathrm{C}$ uptake with Coscinodiscus (self-absorption).

Experiment was done on 16-2-1970

\begin{tabular}{c|c}
$\begin{array}{c}\text { Thickness on filters } \\
\mathrm{mg} / \mathrm{cm}^{2}\end{array}$ & $\begin{array}{c}\text { Count } \\
\text { (Light) }\end{array}$ \\
\hline $1.15^{1}$ ) & 18610 \\
1.96 & 15770 \\
3.07 & 10900 \\
3.31 & 10780 \\
5.78 & 3710
\end{tabular}

1) with culture only (without any added inert material)
Table 10. Effect of increasing quantities of suspended material on the ${ }^{14} \mathrm{C}$ uptake with Ceratium (self-absorption) Experiment was done on 10-3-1070

\begin{tabular}{c:c}
$\begin{array}{c}\text { Thickness on filters } \\
\mathrm{mg} / \mathrm{cm}^{2}\end{array}$ & $\begin{array}{c}\text { Counts } \\
\text { (Light) }\end{array}$ \\
\hline $\left.0.67^{1}\right)$ & 5470 \\
0.79 & 5228 \\
1.24 & 4699 \\
1.65 & 3728 \\
1.82 & 3689 \\
2.11 & 3225
\end{tabular}

1) with culture only (without any added inert material) 
stock solutions. A self-absorption curve is constructed, which is extrapolated to zero thickness. The extrapolation is also done mathematically by assuming that the self-absorption either follows an exponential function or a hyperbolic function. The reliability of the $\mathrm{BaCo}_{3}$ method for determining self-absorption was questioned by the participants of Working Group-24. They were of the opinion that it has no relevance to the suspended material found in nature for which the correction of self-absorption is to be applied. Moreover, in environments like the turbid estuaries, two factors operate simultaneously - the light attenuation in bottles during incubation and the thickness of living plus dead material deposited on filters. Both these factors depend upon the quality and quantity of material in suspension. It was therefore thought necessary to obtain detailed information on the loss of activity for the combined effect of light attenuation and self-absorption by using such materials as are normally found in nature.

\section{a) Experimental procedure}

Bottom mud from an estuary (Cochin Backwater) was collected, autoclaved and dried at $60{ }^{\circ} \mathrm{C}$. After drying, the mud formed flakes which were reduced to fine powder by grinding. The ground material was resuspended in Millipore-filtered seawater and different volumes of this material were added to $100 \mathrm{ml}$ bottles containing diluted cultures (see Part 2). The cultures plus the added inert material formed the total seston which was incubated with ${ }^{14} \mathrm{C}$ as described in Part 2. The quantity of seston deposited on the filters was determined by weighing the filters accurately before and after filtration (when the filters attained a constant weight after drying). Replicate sets of bottles, all of the same size $(100 \mathrm{ml})$, were used with each set of experiments.

\section{b) Results}

Tables 9 and 10 give the counts in the light bottles with increasing thickness of inert material. The counts progressively decrease as the quantity of inert material increases.

Tables 11 and 12 give the counts in the dark bottles in relation to thickness of filters. With Coscinodiscus, the counts in the dark bottles were variable, giving no indication of a clear effect of self-absorption in the dark (Table 11). With Ceratium, on the other hand, there was a progressive increase in the counts with increasing thickness (Table 12). Two more experiments with Dunaliella and Peridinium (Tables 13 and 14) failed to provide a clear evidence of any consistency or predictable change in the loss of activity in the dark bottles from thickness or self-absorption.

Tables 15 and 16 give the complete data on the effect of self-absorption on the rate of photosynthesis of Coscinodiscus and Ceratium. As can be seen from Table 15, with about 5 times increase in the thickness, the loss of activity was approximately 5 times. In Ceratium, however, 3 times increase in the thickness gave a two-fold reduction in the counts (Table 16). In Fig. 1 the corrected counts for Coscinodiscus and Ceratium in relation to thickness on filters have been plotted on a logarithmic scale.

From the two curves (Fig. 1), the correction factors for self-absorption can be determined. These have been given in Table 17. The correction factors in both the organisms agreed very closely. These correction coefficients are entirely different from those derived from $\mathrm{BaCO}_{3}$ precipitates (SMall 1967, SonokiN 1969). 
Table 11. Effect of increasing quantities of inert material on the dark uptake with Coscinodiscus (self-absorption).

Experiment was done on 16-2-1970

\begin{tabular}{c:c}
$\begin{array}{c}\text { Thickness on filters } \\
\mathrm{mg} / \mathrm{cm}^{2}\end{array}$ & $\begin{array}{c}\text { Counts } \\
\text { (Dark) }\end{array}$ \\
\hline $1.22^{1}$ ) & 343 \\
1.45 & 349 \\
1.82 & 445 \\
3.44 & 370 \\
5.67 & 213
\end{tabular}

1) with culture only (without any added inert material)

Table 12. Effect of increasing quantities of inert material on the dark uptake with Ceratium (self-absorption). Experiment was done on 10-3-1970

\begin{tabular}{cc}
$\begin{array}{c}\text { Thickness on filters } \\
\mathrm{mg} / \mathrm{cm}^{2}\end{array}$ & $\begin{array}{c}\text { Counts } \\
\text { (Dark) }\end{array}$ \\
\hline $0.76^{1}$ ) & 163 \\
0.86 & 209 \\
0.87 & 217 \\
0.93 & 249 \\
1.15 & 249 \\
1.73 & 233 \\
2.11 & 280
\end{tabular}

1) with culture only (without any added inert material)

Table 13. Effect of increasing quantities of inert material on the dark uptake with Dunaliella

(self-absorption). Experiment was done on 23-2-1970

$\begin{array}{cc}\begin{array}{c}\text { Thickness on filters } \\ \mathrm{mg} / \mathrm{cm}^{2}\end{array} & \begin{array}{c}\text { Counts } \\ \text { (Dark) }\end{array} \\ 0.85^{1} \text { ) } & 119 \\ 1.07 & 216 \\ 1.13 & 202 \\ 1.67 & 352 \\ 2.24 & 591\end{array}$

1) with culture only (without any added inert material) 
Table 14. Effect of increasing quantities of inert material on the dark uptake with Peridinium.

Experiment was done on 17-3-1970 Thickness on filters
$\mathrm{mg} / \mathrm{cm}^{3}$

$1.22^{1}$ )
1.44
1.62
1.82
2.71
3.02

Counts

(Dark)

1) with culture only (without any added inert material)

Table 15. Effect of self-absorption on the rate of photosynthesis of Coscinodiscus. Experiment was done on 16-2-1970

\begin{tabular}{c|c|cc}
\hline $\begin{array}{c}\text { Thickness } \\
\mathrm{mg} / \mathrm{cm}^{3}\end{array}$ & \multicolumn{2}{c}{ Counts } & $\begin{array}{c}\text { Rate of photosynthesis } \\
\mathrm{mgC} / \mathrm{m}^{3} / \mathrm{h}\end{array}$ \\
& (Light) & (Dark) & \\
$\left.1.15^{1}\right)$ & $(18267)$ & $(343)$ & 27.86 \\
1.96 & $(15325)$ & $(445)$ & 23.93 \\
3.07 & $(10530)$ & $(370)$ & 16.44 \\
3.31 & $(10410)$ & $(370)$ & 16.25 \\
5.78 & $(3497)$ & $(213)$ & 5.46 \\
$1)$ with cultures only (without any added inert material)
\end{tabular}

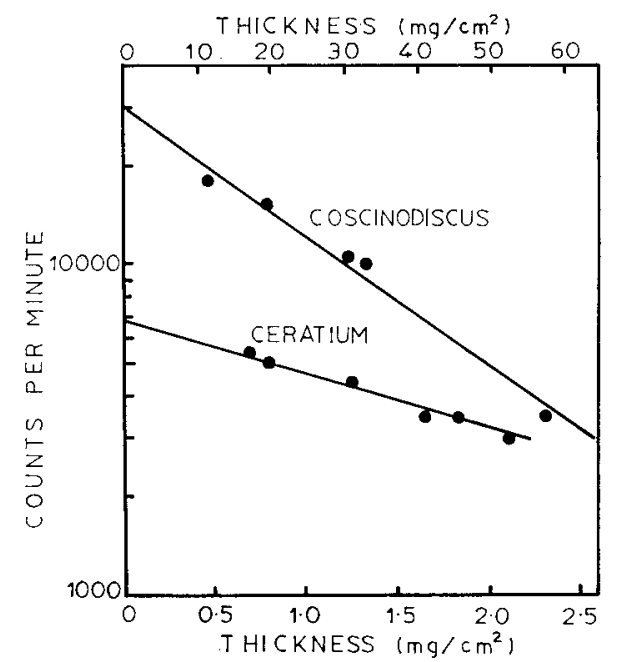

Fig. 1. Self-absorption curve showing the relationship between the activity (counts) and the amount of material (inert + culture) deposited on the filters. Inert material consisted of fine particles of estuarine silt in suspension added in varying proportions to a given volume of unialgal cultures of Coscinodiscus and Ceratium. Thickness along the top abscissa refers to Coscinodiscus and along the bottom refers to Ceratium. 
Table 16. Effect of self-absorption on the rate of photosynthesis of Ceratium. Experiment was done on 11-2-1970

\begin{tabular}{c|c|c|c}
\multirow{2}{*}{$\begin{array}{c}\text { Thickness } \\
\mathrm{mg} / \mathrm{cm}^{2}\end{array}$} & \multicolumn{2}{|c|}{ Counts } & $\begin{array}{c}\text { Rate of photosynthesis } \\
\mathrm{mgC} / \mathrm{m}^{3} / \mathrm{h}\end{array}$ \\
& (Light) & (Dark) & \\
$\left.0.67^{1}\right)$ & $(5307)$ & $(163)$ & 7.10 \\
0.79 & $(5044)$ & $(184)$ & 6.75 \\
1.24 & $(4450)$ & $(249)$ & 5.95 \\
1.65 & $(3495)$ & $(233)$ & 4.68 \\
1.82 & $(3456)$ & $(233)$ & 4.62 \\
2.11 & $(3062)$ & $(163)$ & 4.09
\end{tabular}

1) with culture only (without any added inert material)

Table 17. Correction coefficients, for selfabsorption by inert material derived from Fig. 1, using 2 organisms, Coscinodiscus and Ceratium

\begin{tabular}{|c|c|c|}
\hline \multirow{2}{*}{$\begin{array}{r}\text { Thickness } \\
\mathrm{mg} / \mathrm{cm}^{2}\end{array}$} & \multicolumn{2}{|c|}{ Organisms } \\
\hline & Coscinodiscus & Ceratium \\
\hline 0 & 1.000 & 1.000 \\
\hline 0.4 & 1.156 & 1.168 \\
\hline 0.8 & 1.337 & 1.363 \\
\hline 1.2 & 1.545 & 1.593 \\
\hline 1.6 & 1.786 & 1.861 \\
\hline 2.0 & 2.065 & 2.173 \\
\hline
\end{tabular}

c) Conclusions

It is clear from the above experiments that the presence of inert material reduces the counts in the light bottles and in turn decreases the rate of primary production. The effect is composite of light attenuation in bottles and selfabsorption on filters. The shape of the self-absorption curve would largely depend upon the type of material in suspension and the counting equipment used. It is possible to apply correction factors within limits, but when the total material deposited on the filters is large, the activity should be measured by a liquid scintillation counter (see e.g. JITTS and ScOTT 1961) or by total combustion and recovery of active $\mathrm{CO}_{2}$ (JENKINS 1965).

\section{Effect of organic pollutants on light and dark bottles}

In polluted waters the load of organic matter and microorganisms is generally heavy. Normally a greater concentration of soluble organic matter is associated with a high population of microbial flora. A large bacterial load leads to a greater uptake of carbon dioxide in the dark and this gives rise to erroneously low values of primary production (SEKI $1967 \mathrm{a}, \mathrm{b}$ ). In such situations it is important to ascertain the extent to which the measurements by ${ }^{14} \mathrm{C}$ method would be reliable and realistic. 


\section{a) Experimental procedure}

Since the organic pollutants or soluble organic substances which contaminate the water could be extremely variable, it was thought best to confine the investigations using the following three constituents which are of common occurrence in most polluted waters, where the source of pollution is largely organic:

(a) Protein (hydrolysed casein was used in experiments)

(b) Carbohydrate (glucose)

(c) High load of bacteria

To begin with, different concentrations of protein and glucose were added to constant volumes of unialgal cultures. Both protein and glucose were autoclaved at $20 \mathrm{lb}$ pressure for 30 minutes to make them, as far as possible, bacteria-free. This procedure is rather important as these constituents, particularly casein, normally contain a large population of bacteria. All other procedures related to incubation with ${ }^{14} \mathrm{C}$, filtration and counting were the same as described in Part 2.

In the next series of experiments, bacteria (Pseudomonas, Achromonas, and Vibrio), which are commonly found in polluted estuaries and inshore waters, were isolated and different concentrations used along with constant volumes of unialgal cultures.

\section{b) Results}

Tables 18-21 give the results of four experiments using different concentrations of soluble organic matter (casein and glucose). From these experiments there is an indication that with increasing concentrations of soluble organic substances, there is an increase in the counts of both light and dark bottles. The

Table 18. Effect of dissolved organic substances on light and dark assimilation of carbon dioxide in Asterionella. Experiment was done on 10-7-1970

\begin{tabular}{|c|c|c|c|c|c|}
\hline \multirow{2}{*}{$\begin{array}{l}\text { Casein } \\
(\mu g / 1)\end{array}$} & \multirow{2}{*}{$\begin{array}{c}\text { Glucose } \\
(\mu g / 1)\end{array}$} & \multicolumn{2}{|c|}{ Counts per minute } & \multirow{2}{*}{$\mathrm{I}_{-}-\mathrm{D}$} & \multirow{2}{*}{$\begin{array}{l}\text { Rate of } \\
\text { photosynthesis } \\
\mathrm{mg} \mathrm{C} / \mathrm{m}^{3} / \mathrm{h}\end{array}$} \\
\hline & & Light (L) & Dark (D) & & \\
\hline $\left.0^{1}\right)$ & $\left.0^{1}\right)$ & 6224 & 93 & 6131 & 16.57 \\
\hline 500 & 1000 & 6403 & 181 & 6222 & 16.81 \\
\hline 1000 & 2000 & 6136 & 198 & 5938 & 16.05 \\
\hline 2500 & 5000 & 6132 & 176 & 5956 & 16.10 \\
\hline
\end{tabular}

1) with cultures only

Table 19. Effect of dissolved substances on light and dark assimilation of carbon dioxide in Asterionella. Experiment was done on 10-7-1970

\begin{tabular}{l|c|c|c|c|c|c}
$\begin{array}{c}\text { Casein } \\
(\mu \mathrm{g} / \mathrm{l})\end{array}$ & $\begin{array}{c}\text { Glucose } \\
(\mu \mathrm{g} / \mathrm{l})\end{array}$ & \multicolumn{2}{|c|}{$\begin{array}{c}\text { Counts per minute } \\
\text { Light (L) }\end{array}$} & $\begin{array}{c}\text { Dark (D) } \\
\text { Late of }\end{array}$ \\
\hline & $\left.0^{1}\right)$ & 3545 & 144 & 3401 & $\begin{array}{c}\text { Lhotosynthesis } \\
\mathrm{mg} / \mathrm{m}^{3} / \mathrm{h}\end{array}$ \\
500 & 1000 & 3621 & 226 & 3395 & 11.06 \\
2000 & 4000 & 3568 & 211 & 3357 & 11.04 \\
5000 & 10000 & 3981 & 220 & 3761 & 11.03 \\
10000 & 20000 & 3972 & 234 & 3738 & 12.16 \\
\\
1) with cultures only \\
39 \\
Internationale Revue, Bd. 57, H. 4
\end{tabular}


Table 20. Effect of dissolved organic substances on light and dark assimilation of carbon dioxide in Chaetoceros. Experiment was done on 17-7-1970

\begin{tabular}{|c|c|c|c|c|c|}
\hline Casein & Glucose & \multicolumn{2}{|c|}{ Counts per minute } & $1 \quad D$ & Rate of \\
\hline & $(\mu \mathrm{g} / 1)$ & Light (L) & $\operatorname{Dark}(\mathrm{D})$ & & $\mathrm{mg} \mathrm{C} / \mathrm{m}^{3} / \mathrm{h}$ \\
\hline $\left.0^{1}\right)$ & $\left.0^{1}\right)$ & 4860 & 211 & 4649 & 10.96 \\
\hline 500 & 1000 & 5042 & 253 & 4789 & 11.29 \\
\hline 2000 & 5000 & 5107 & 278 & 4829 & 11.39 \\
\hline 10000 & 20000 & 5611 & 323 & 5288 & 12.47 \\
\hline
\end{tabular}

Table 21. Effect of dissolved organic substances on light and dark assimilation of carbon dioxide in Coscinodiscus. Experiment was carried out on 18-7-1970

\begin{tabular}{c|c|c|c|c|c}
$\begin{array}{c}\text { Casein } \\
(\mu g / \mathrm{l})\end{array}$ & $\begin{array}{c}\text { Glucose } \\
(\mu \mathrm{g} / \mathrm{l})\end{array}$ & $\begin{array}{c}\text { Counts per minute } \\
\text { Light }(\mathrm{L})\end{array}$ & Dark (D) & & $\begin{array}{c}\text { L }-\mathrm{D} \\
\text { Rate of } \\
\text { photosynthesis } \\
\mathrm{mg} / \mathrm{m}^{3} / \mathrm{h}\end{array}$ \\
\hline $\left.0^{1}\right)$ & $\left.0^{1}\right)$ & 7826 & 428 & 7398 & 20.46 \\
38 & 75 & 8011 & 434 & 7577 & 20.96 \\
188 & 375 & 8103 & 441 & 7662 & 21.21 \\
375 & 750 & 8151 & 539 & 7612 & 21.05 \\
750 & 1500 & 8160 & 594 & 7566 & 20.93 \\
\hline
\end{tabular}

rate of primary production, however, is not affected significantly, although the available data suggest that the production values are enhanced slightly (see
Tables 19, 20 and 21 ).

In the next series of experiments, the effect of different concentrations of bacterial flora was investigated. Tables $22-24$ give the results of these experiments. From these tables it is clear that with a gradual increase in the bacterial load, the dark uptake goes on increasing progressively leading to a progressive decrease in the estimated values of the rate of photosynthesis.

Table 22. Effect of different concentrations of Vibrio (bacteria), when used with constant volumes of Chaetoceros, on the light and dark assimilation of carbon dioxide. Experiment was done on 29-7-1970

\begin{tabular}{|c|c|c|c|c|}
\hline \multirow{2}{*}{$\begin{array}{c}\text { Vibrio } \\
\text { (counts/l) }\end{array}$} & \multicolumn{2}{|c|}{ Counts per minute } & \multirow[b]{2}{*}{$\mathrm{L}_{1}-\mathrm{D}$} & \multirow{2}{*}{$\begin{array}{l}\text { Rate of photosynthesis } \\
\mathrm{mg} \mathrm{C} / \mathrm{m}^{3} / \mathrm{h}\end{array}$} \\
\hline & Light (L) & Dark (D) & & \\
\hline $\left.0^{1}\right)$ & 10268 & 317 & 9951 & 25.63 \\
\hline $5 \times 10^{3}$ & 10207 & 374 & 9833 & 25.32 \\
\hline $1 \times 10^{4}$ & 10203 & 390 & 9813 & 25.27 \\
\hline $5 \times 10^{4}$ & 10157 & 370 & 9787 & 25.20 \\
\hline
\end{tabular}


Table 23. Effect of different concentrations of Pseudomonas (bacteria), when used with constant volumes of Chaetoceros, on the light and dark assimilation of carbon dioxide. Experiment was done on 29-7-1970

\begin{tabular}{|c|c|c|c|c|}
\hline \multirow{2}{*}{$\begin{array}{l}\text { Pseudomonas } \\
\quad(\text { counts } / \mathbf{l})\end{array}$} & \multicolumn{2}{|c|}{ Counts per minute } & \multirow{2}{*}{$\mathrm{L}-\mathrm{D}$} & \multirow{2}{*}{$\begin{array}{l}\text { Rate of photosynthesis } \\
\qquad \mathrm{mg} \mathrm{C} / \mathrm{m}^{3} / \mathrm{h}\end{array}$} \\
\hline & Light (L) & Dark (D) & & \\
\hline $\left.0^{1}\right)$ & 10268 & 317 & 9951 & 25.63 \\
\hline $5 \times 10^{3}$ & 10306 & 581 & 9725 & 25.04 \\
\hline $1 \times 10^{4}$ & 10220 & 700 & 9520 & 24.51 \\
\hline $5 \times 10^{4}$ & 10322 & 737 & 9585 & 24.68 \\
\hline
\end{tabular}

Table 24. Effect of different concentrations of Achromonas (bacteria), when used with constant volumes of Coscinodiscus, on the light and dark assimilation of carbon dioxide. Experiment was done on 31-7-1970

\begin{tabular}{|c|c|c|c|c|}
\hline \multirow{2}{*}{$\begin{array}{l}\text { Achromonas } \\
\text { (counts/1) }\end{array}$} & \multicolumn{2}{|c|}{ Counts per minute } & \multirow{2}{*}{$\mathrm{L}-\mathrm{D}$} & \multirow{2}{*}{$\begin{array}{c}\text { Rate of photosynthesis } \\
\mathrm{mg} \mathrm{C} / \mathrm{m}^{3} / \mathrm{h}\end{array}$} \\
\hline & Light (L) & Dark (D) & & \\
\hline $\left.0^{1}\right)$ & 1807 & 303 & 1504 & 3.28 \\
\hline $2 \times 10^{3}$ & 1843 & 307 & 1536 & $\mathbf{3 . 3 5}$ \\
\hline $1 \times 10^{4}$ & 1875 & 320 & 1555 & 3.39 \\
\hline $2 \times 10^{4}$ & 1811 & 322 & 1489 & 3.24 \\
\hline $2 \times 10^{5}$ & 1802 & 320 & 1482 & 3.23 \\
\hline
\end{tabular}

With still higher populations of bacteria, the uptake both in the light and dark bottles becomes very high and the relationship between the two becomes totally disproportionate. The dark uptake may even exceed the counts from the light bottles (Tables $25-27$ ), resulting into very erroneous and unrealistic values of primary production.

Table 25. Effect of different concentrations of Pseudomonas (bacteria), when used with constant volumes of Ceratium, on the light and dark assimilation of carbon dioxide. Experiment was done on 10-3-1970

\begin{tabular}{|c|c|c|c|c|}
\hline \multirow{2}{*}{$\begin{array}{l}\text { Pseudomonas } \\
\text { (counts/l) }\end{array}$} & \multicolumn{2}{|c|}{ Counts per minute } & \multirow{2}{*}{$\mathrm{L}-\mathrm{D}$} & \multirow{2}{*}{$\begin{array}{l}\text { Rate of photosynthesis } \\
\mathrm{mg} \mathrm{C} / \mathrm{m}^{3} / \mathrm{h}\end{array}$} \\
\hline & Light (L) & Dark (D) & & \\
\hline $\left.0^{1}\right)$ & 1632 & 141 & 1491 & 2.00 \\
\hline $2.5 \times 10^{7}$ & 6126 & 4075 & 2051 & 2.74 \\
\hline $5.0 \times 10^{7}$ & 5974 & 4156 & 1818 & 2.43 \\
\hline $10^{8}$ & 6062 & 5381 & 681 & 0.91 \\
\hline
\end{tabular}


Table 26. Effect of different concentrations of Achromonas (bacteria), when used with constant volumes of Coscinodiscus, on the light and dark assimilation of carbon dioxide. Experiment was done on 11-3-1970

\begin{tabular}{|c|c|c|c|c|}
\hline \multirow{2}{*}{$\begin{array}{r}\text { Achromonas } \\
(\text { counts } / 1)\end{array}$} & \multicolumn{2}{|c|}{ Counts per minute } & \multirow{2}{*}{$\mathrm{L}-\mathrm{D}$} & \multirow{2}{*}{$\begin{array}{l}\text { Rate of photosynthesis } \\
\qquad \mathrm{mg} \mathrm{C} / \mathrm{m}^{3} / \mathrm{h}\end{array}$} \\
\hline & Light (L) & Dark (D) & & \\
\hline $\left.0^{1}\right)$ & 2215 & 182 & 2033 & 2.91 \\
\hline $10^{7}$ & 6314 & 4346 & 1968 & 2.84 \\
\hline $2 \times 10^{7}$ & 9135 & 6051 & 3084 & 4.44 \\
\hline $4 \times 10^{7}$ & 9649 & 8995 & 654 & 0.91 \\
\hline
\end{tabular}

Table 27. Effect of different concentrations of Vibrio (bacteria), when used with constant volumes of Coscinodiscus, on the light and dark assimilation of carbon dioxide. Experiment was done on 11-3-1970

\begin{tabular}{l|cc|c|c}
$\begin{array}{c}\text { Vibrio } \\
\text { (counts/l) }\end{array}$ & \multicolumn{2}{|c|}{ Counts per minute } & L $-\mathrm{D}$ & $\begin{array}{c}\text { Rate of photosynthesis } \\
\mathbf{m g ~ C} / \mathrm{m}^{3} / \mathrm{h}\end{array}$ \\
\hline & Light (L) & Dark (D) & & 2.93 \\
$\left.0^{1}\right)$ & 2215 & 182 & 2033 & 2.90 \\
$10^{7}$ & 4903 & 2893 & 2010 & $\mathbf{3 . 4 4}$ \\
$2 \times 10^{7}$ & 6194 & 3805 & 2389 & $\mathrm{Nil}$ \\
$4 \times 10^{7}$ & 5664 & 6232 & - &
\end{tabular}

c) Conclusions

In polluted waters it is questionable whether the ${ }^{14} \mathrm{C}$ technique can give satisfactory results. The success of the technique will, to a large extent, depend upon the degree and type of pollution. If the pollutants largely include dissolved organic matter, the productivity values may not be affected markedly. However, soluble organic matter in nature seldom remains free from bacteria. If the bacterial population is low (see Tables $22-24$ ), the effect on the rate of production may not be too pronounced. If the bacterial load is too high, the productivity values obtained will not be reliable. The check to the applicability of the method seems to lie in the dark bottle uptake. If it is more than $10 \%$ of the light bottles, the method is bound to give highly erratic and erroneous results.

\section{Summary}

1. Several series of experiments were conducted to demonstrate the effects of certain conditions on the measurement of primary production by the ${ }^{14} \mathrm{C}$ method. In short-term experiments, bottle size had no appreciable effect on the rate of production.

2. The simulated effect of inert material (estuarine silt) was very pronounced on the incubation of samples, as the material deposited on the filters (thickness) reduced the activity by self-absorption. The combined effect of light attenuation in bottles and thickness on the loss of activity was determined.

3. Soluble organic matter (protein and carbohydrate) showed no marked effect on the rate of production, but the addition of large bacterial populations gave a highly variable 
effect on both light and dark counts. This indicates that in polluted waters, which are generally characterized by a heavy bacterial load, the use of ${ }^{14} \mathrm{C}$ technique may give erroneous results.

\section{Acknowledgement}

We thank Dr. N. K. Panikkar for the encouragement we received from him.

\section{Literature cited}

IBP HANDBOOK No. 12, 1969: A manual on methods for measuring primary production in aquatic environments. Ed. R. A. VolLeNweroer. - Blackwell Scientific Publications, Oxford and Edinburgh, $213 \mathrm{pp}$.

Jenkins, D., 1965: Determination of primary productivity of turbid waters with carbon-14. - J. Water Poll. Cont. Fed. 37 : $1281-1288$.

Jitтs, H. R., and SсотT, B. D., 1961: The determination of zero thickness activity in Geiger counting of C-14 solutions used in marine productivity studies. - Limnol. Oceanogr. 6: $116-123$.

NATIONAL ACADEMY OF SCIENCES, 1969: Recommended procedures for measuring the productivity of plankton standing stock and related oceanic properties. - Printing and Publishing Office, NAS, Wash. D. C., $59 \mathrm{pp}$.

SCOR, 1969: Estimation of primary production under special conditions. - Report of SCOR Working Group 24, Proc. SCOR 5: 14-20.

SEKI, H., 1967a: Effect of organic nutrients on dark assimilation of carbon dioxide in the sea. - Inf. Bull. Planktol. Japan, Commemoration Number of Dr. Y. MATsue : 201 - 205. $1967 \mathrm{~b}$ : Effect of organic nutrients on dark assimilation of carbon dioxide in the sea. II. Dark assimilation of marine diatoms. - Inf. Bull. Planktol. Japan 14: 22-25.

SMALL, L. F., 1967: On the standardization of $\mathrm{C}^{14}$ for primary production estimates in aquatic environments. - Iowa St. J. Sci. 42: 63-7l.

Soeder, C. J., and Talling, J. F., 1969: The enclosure of phytoplankton communities. -In: IBP Handbook No. 12, Ed. R. A. Vollenweider. - Blackwell Scientific Publications, Oxford and Edinburgh: $62-70$.

Sorokin, Y.I., 1969: Standardisation procedure used. - In: IBP Handbook No. 12. Ed. R. A. Voleenweider. - Blackwell Scientific Publication, Oxford and Edinburgh: $57-59$.

Stemmann Nielsen, E., 1952: The use of radio-active carbon $\left(\mathrm{C}^{14}\right)$ for measuring organic production in the sea. - J. Cons. perm. int. Explor. Mer. 18: 117-140.

Strickland, J. D. H., and Parsons, T. R., 1968: A practical handbook of seawater analysis, 3 ed. - Bull. Fish. Res. Bd. Canada $167: 311 \mathrm{pp}$.

UNESCO, 1967: Report of a meeting of the joint group of experts on radio-carbon estimation of primary production. - Unesco Tech. Papers Mar. Sci. 6, 6 pp.

Dr. S. Z. QASIM

Central Marine Fisheries Research Institute, Gopala Prabhu Road,

Cochin-11. Kerala. India. 